\title{
Profile of Patients with Intracranial Tumors Undergoing Surgical Resection at a Neuro-oncology Referral Hospital
}

\section{Perfil dos pacientes com tumores intracranianos submetidos a ressecção cirúrgica em um hospital de referência neuro-oncológica}

\author{
Marcelo Lemos Vieira da Cunha ${ }^{1}$ Luiza Grosbelli \\ ${ }^{1}$ Neurosurgery, Hospital Regional do Oeste, Chapecó, SC, Brazil \\ 2 Universidade Comunitária da Região de Chapecó (UNOCHAPECÓ), \\ Chapecó, SC, Brazil

\begin{abstract}
Address for correspondence Marcelo Lemos Vieira da Cunha, MD, MSc, Rua Lauro Muller, 224e, apto 501, Centro, CEP 89801-600, Chapecó,
\end{abstract} \\ SC - Brazil (e-mail: marcelolvc@yahoo.com.br).
}

Arq Bras Neurocir 2018;37:19-26.

\begin{abstract}
Keywords

- brain neoplasms

- neurosurgery

- neurosurgical procedures

- epidemiology

- surgical oncology
\end{abstract}

\section{Resumo}

Objectives To analyze the epidemiological aspects of primary and metastatic tumors of the central nervous system (CNS) among patients operated on by a single surgeon dedicated to neuro-oncology at Hospital Regional do Oeste, in Chapecó (Santa Catarina, Brazil), between 2013 and 2016.

Methods Cross-sectional, retrospective, and observational analysis of 347 patients undergoing surgery due to intracranial tumors. The patients' data were obtained from the hospital registry, medical records, and pathology reports.

Results Primary CNS tumors comprised $72.1 \%$ of the sample. There was a predominance of females (52.7\%), and the mean age was 49.3 years, with a peak of incidence between the ages of 25 and 64 years. Gliomas were the most common primary brain tumors (23.7\%), followed by meningiomas (17.0\%). Lung cancer (15.3\%), breast cancer (4.9\%), and melanoma (3.5\%) were, in descending order, the most frequent primary sites of metastases, which were recorded in 97 cases (27.9\%).

Conclusion The lack of standardization in the process of notification of tumor diseases imposes challenges in the establishment of estimates close to the real ones, preventing improvement of public health care policies to protect patients with neuro-oncological conditions. Based on the current model, regionalization of the data seems to be the best option in the management of this subgroup of patients.

Objetivos Analisar aspectos epidemiológicos dos tumores cerebrais primários e metastáticos entre os pacientes operados por um único cirurgião dedicado à neurooncologia no Hospital Regional do Oeste, em Chapecó, SC, Brasil, durante os anos de 2013 a 2016. ISSN 0103-5355.
Copyright $(2018$ by Thieme Revinter

Publicações Ltda, Rio de Janeiro, Brazil
License terms

(c) (i) $\ominus$ (\$) 


\author{
Palavras-chave \\ - neoplasia \\ cerebral \\ - neurocirurgia \\ - procedimentos \\ neurocirúrgicos \\ - epidemiologia \\ - cirurgia \\ oncológica
}

\begin{abstract}
Métodos Estudo transversal, retrospectivo, do tipo observacional, com análise de 347 casos de neoplasias intracranianas de acordo com os dados obtidos no setor de registro hospitalar, nos prontuários da instituição e registros anatomopatológicos dos pacientes tratados cirurgicamente.

Resultados Tumores cerebrais primários corresponderam a $72.1 \%$ da amostra. Houve predomínio do sexo feminino (52,7\%) e a média de idade foi de 49,3 anos, com pico de incidência na faixa etária de 25 a 64 anos. Gliomas foram os tumores cerebrais primários mais encontrados (23.7\%), seguidos por meningiomas (17,0\%). Cânceres de pulmão (15,3\%), mama (4,9\%) e melanoma (3,5\%) foram, em ordem decrescente, as localizações primárias mais frequentes das metástases registradas em 97 casos (27.9\%).

Conclusão A dificuldade em se estabelecer uma estimativa mais próxima da realidade devido à falta de padronização na notificação de agravos tumorais impede uma melhor condução de políticas públicas de amparo ao paciente neuro-oncológico. Assim, nos moldes atuais, a regionalização dos dados parece a melhor opção na administração desse subgrupo de pacientes.
\end{abstract}

\section{Introduction}

Tumors of the central nervous system (CNS) account for $1.5 \%$ of all cancers and $2.4 \%$ of all cancer-related deaths annually. ${ }^{1,2}$ Primary brain tumors affect between 11 and 19 per 100,000 individuals, ${ }^{3}$ while brain metastases affect 11 out of 100,000 individuals in the general population. Additionally, necropsy studies show that up to $25 \%$ of the patients with malignancies have metastases to the CNS. ${ }^{4}$

Since the mid-1980s, epidemiological studies have pointed out to an increased incidence of CNS tumors in different countries, which is most pronounced in elderly individuals. ${ }^{5}$ Some hypotheses to explain this observation include the dissemination of computerized tomography (CT) scans, infectious diseases (such as AIDS), and use of mobile phones, in addition to others that still lack a solid foundation. Both incidence and mortality associated with these tumors have increased in most developed countries, especially in groups with more advanced age. In most of these countries, the mortality associated with these malignancies occupies the $12^{\text {th }}$ position of all deaths. ${ }^{6}$

The supratentorial location is the most frequent CNS site of tumors in adults, and gliomas (astrocytomas, ependymomas, oligodendrogliomas) account for more than $30 \%$ of the tumors in this group, followed by meningiomas and schwannomas. In children, the most common location is the infratentorial region, with medulloblastomas, ependymomas, and cerebellar astrocytomas featuring as the most frequent histological types. ${ }^{2}$

Secondary neoplasms are classified according to their primary location, and the primary tumors that most commonly evolve to metastases to the CNS in adults are bronchogenic carcinoma (mainly small-cell carcinoma and adenocarcinoma), breast cancer, renal carcinoma, melanoma, and malignant neoplasms of the gastrointestinal tract. However, the primary site of up to $10 \%$ of all brain metastases is unknown. ${ }^{7-10}$ Among patients younger than 21 years, CNS metastases originate mainly from sarcomas (osteogenic sarcoma, rhabdomyosarcoma, and Ewing's sarcoma) and germ cells tumors. ${ }^{4}$

Although the incidence of CNS tumors is lower than that of other tumors, brain tumors assume great importance in oncology and stand out in the context of new research and treatments, due to great advances in the genetic and molecular fields of treatment obtained with new discoveries about the etiology of these tumors. Intracranial metastases are still considered the most frequent and fearsome neurological complication of all cancers. ${ }^{11}$ In addition to the high indexes of functional deficit and the importance of brain metastases in the prognosis of other cancers, brain tumors stand out in the oncological field. There are a disproportionate number of deaths and sequels compared with other types of cancers, making CNS tumors an important public health care problem.

Based on the above considerations, the present study aimed to analyze the epidemiological aspects of primary and metastatic brain tumors among patients operated on by a single neurosurgeon dedicated to neuro-oncology between 2013 and 2016 at the Hospital Regional do Oeste, in Chapecó (Santa Catarina, Brazil), a tertiary referral center for approximately one million individuals.

\section{Methods}

This was a cross-sectional, retrospective, and observational analysis of the incidence of primary and metastatic intracranial tumors of patients operated on by a single neurosurgeon dedicated to neuro-oncology at Hospital Regional do Oeste. We obtained the data from the patients' medical records, maintained at the hospital, along with the pathology reports of all patients surgically treated at our center. We included only data from patients who had undergone a neurosurgical procedure between January of 2013 and December of 2016, which included the patients' gender, age, tumor location, and 
histological type. The study population was divided into the following age groups: children ( $<14$ years), young adults (15-24 years), adults (25-64 years), and elderly ( $>65$ years). We excluded all incomplete and/or inconclusive data, as well as patients with tumors of the spinal cord, spinal column, and cauda equina.

We initially analyzed a total of 398 patients with a diagnosis of "intracranial tumor" (ICD-10 codes C71, D43, C71.9, D32, and D33) who had undergone surgical treatment by the same neurosurgeon with a focus on neuro-oncology, in addition to data gathered by the neurosurgeon's own records, which were subsequently verified against the hospital records. Patients submitted to new neurosurgical treatments due to relapse and/or diagnosis of inflammatory lesions (parasites, fungal, and bacterial) were excluded from the analysis.

After analyzing the obtained clinical records and histopathological reports, we selected 347 patients who were further subdivided according to the tumors' histological type and topography. The data were then analyzed and regrouped according to the 2007 World Health Organization (WHO) classification of brain tumors. ${ }^{12}$ We adopted the 2007 WHO classification for this purpose, instead of the more recent 2016 one, since the latter takes into consideration molecular parameters, which were not available in our cohort at the time of data collection.

\section{Statistical Analysis}

The variables were organized on tabulated databases for further processing using the software programs Microsoft Office Excel 2010 (Microsoft Corporation, Redmond, WA, USA) and BioEstat 5.0 (Instituto Mamirauá, Tefé, AM, Brazil). The data were organized in tables for further analysis.

The level of measurement of the observed variables "histology" and "sex" was nominal and did not require a normality test to prove the lack of this assumption. The normality of the variable "age" was verified using the Lilliefors test.

The chi-square test was applied to analyze differences in frequency between age groups, the most frequent diagnostic classes, and comparisons between the genders. However, when the frequencies were too small, the Fisher exact test was instead applied. To compare the diagnostic categories for the age groups, we applied the Kolmogorov-Smirnov test for independent samples.

All statistical analyses were performed with the software Statistica 7.0 (StatSoft Inc., Tulsa, OK, USA) and the level of significance was set at $5 \%$.

\section{Results}

We analyzed 347 patients who attended the Neurosurgery Unit at the Western Regional Hospital from January of 2013 to December of 2016. Of all, 183 were women (52.7\%) and 164 were men (47.3\%), and the mean age was 49.3 years (minimum 46 days, maximum 91 years). The mean age among female patients was 47.7 years and among males, it was 51.3 years. No statistically significant difference was observed when we compared the frequencies of men and women (chi-square test, $p=0.494$ ). However, there was a slightly increased prevalence of the female gender in all histological types analyzed (51.3\%). When we compared the histological types against both genders, we observed two distinct groups $(p<0.05)$, with a predominance of women in the categories of meningiomas (74.6\%) and breast metastasis (100\%), and a predominance of men in the categories of lung metastasis (58.5\%) and glioblastoma (59.1\%) (of note, this analysis included only the subtypes with more than 15 cases).

A progressive increase in the number of patients with CNS tumors undergoing neurosurgical treatment for cancer was observed after 2014, when one of the neurosurgeons of our center began to focus on these patients' care. In 2015, a neuro-oncology outpatient clinic was inaugurated, which has been offering, to date, multidisciplinary care to patients with CNS tumors, including radiotherapy, radiology, neurosurgery, pathology, and oncology. With a team specifically dedicated to the care of patients with CNS tumors, there was an increase in the number of patients referred from the public health care system to our center to receive advanced care. Therefore, the increased number of patients observed after 2014 is attributed to the improved flow of the care offered to the patients, mainly in the public health care system, but also in the private sector. These patients receive a more efficient and prompt care and, on the same day, are evaluated by several professionals who discuss their initial and follow-up management and evaluate their treatment response. As shown in - Fig. 1, the number of patients increased from 59 in 2013 to 85 in 2014, 98 in 2015, and 105 in 2016.

Regarding the location of the tumor in the CNS, 52.7\% ( $n=183$ ) were located in the supratentorial compartment, $19.9 \%(n=69)$ in the infratentorial compartment, $17.0 \%$ $(n=59)$ involved the meninges, $8.6 \%(n=30)$ affected the sellar region, and $1.7 \%(n=6)$ were detected in the ventricular cavity (-Fig. 2). A greater prevalence of tumors was found in the 25-64 age group (250 patients, $72 \%$ of the total cases analyzed; $p<0.0001$ ) ( - Table 1 ). A comparison among histological types using the chi-square test revealed a significantly $(p<0.05)$ increased frequency of the following categories: meningiomas $(n=59)$, lung metastasis ( $n=53)$, and glioblastoma $(n=44)$.

A total of 250 patients had primary tumors (72.0\%), and 97 had metastases to the CNS (28.0\%). Among the primary brain tumors, meningeal tumors were the most prevalent (17.0\%), followed by glioblastomas (12.7\%) and pituitary tumors (7.5\%) (-Table 2).

When we compared the histological types by age groups using the Kolmogorov-Smirnov test, we observed two distinct groups ( $p<0.05)$ : Group A, which included high-grade gliomas, oligodendrogliomas, metastases, lymphomas, meningiomas, schwannomas, and pituitary tumors, and comprised $98 \%$ of the patients above the age of 25 years; and Group B, which included low-grade gliomas and other types of tumors, and comprised $83 \%$ of the cases under the age of 25 years. 


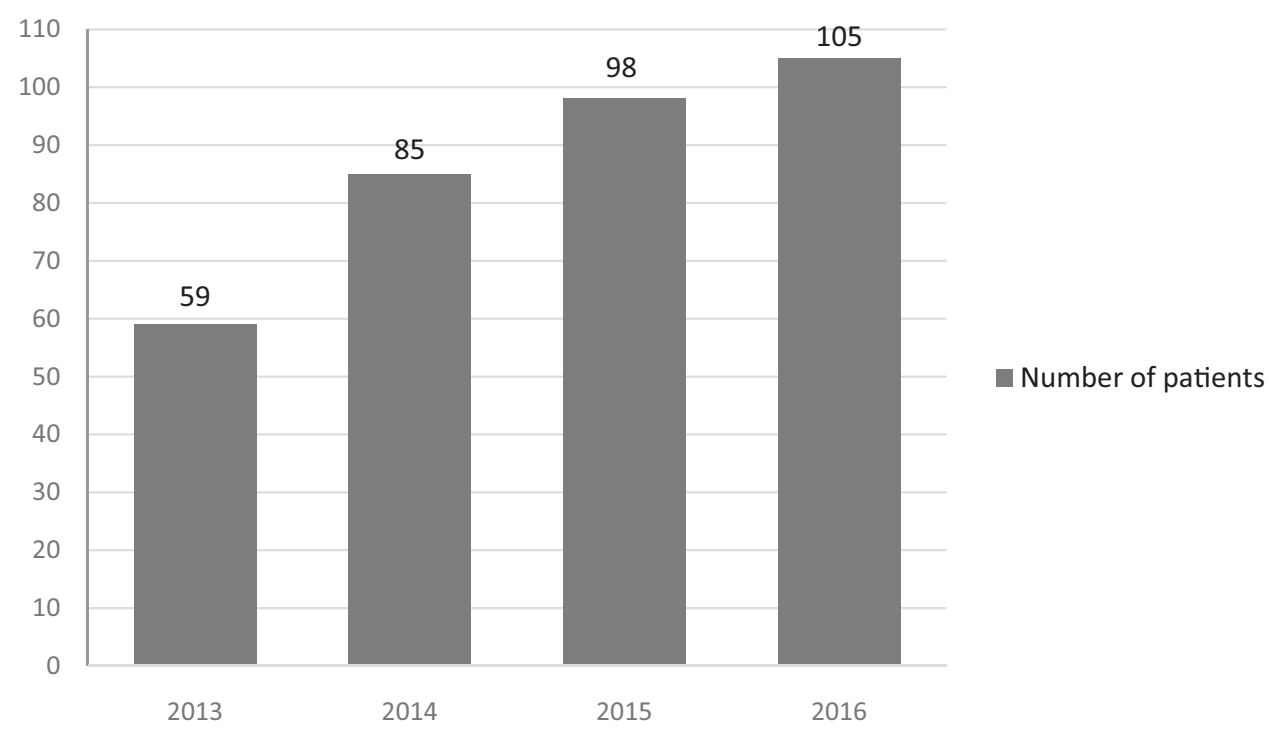

Fig. 1 Number of patients with intracranial neoplasms submitted to surgical resection at Hospital Regional do Oeste (Chapecó, SC, Brazil) between 2013 and 2016, performed by a single surgeon dedicated to neuro-oncology. The data are stratified by year (2013-2016).

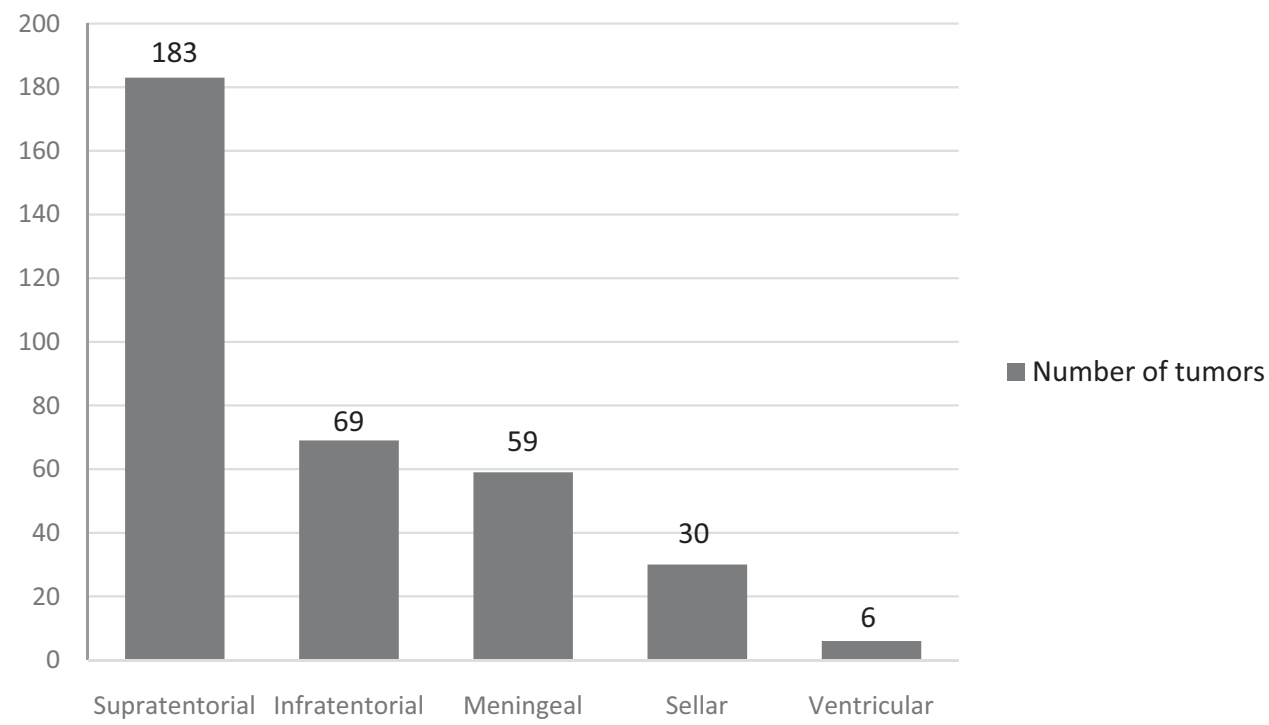

Fig. 2 Number of intracranial neoplasms submitted to surgical resection at Hospital Regional do Oeste (Chapecó, SC, Brazil) between 2013 and 2016, performed by a single surgeon dedicated to neuro-oncology. The data are stratified by tumor location.

\section{Discussion}

Tumors affecting the CNS comprise a group of very heterogeneous diseases. These tumors are less frequent than nonCNS neoplasms, but their incidence and mortality have been increasing over the past decades across several countries, especially among the elderly. ${ }^{13-15}$ According to a study by Baldi et al, CNS tumors occupy the $15^{\text {th }}$ and $13^{\text {th }}$ positions among the most common tumors affecting men and women respectively. ${ }^{5}$ In Brazil, CNS tumors are responsible for $\sim 2.5 \%$ of all cases of cancer and occupy the $10^{\text {th }}$ position in incidence for both men and women. ${ }^{3}$

Analyses of cancer prevalence are the best indicators of survival associated with this disease and potential long-term prophylactic implications. Still, the incidence of some types of cancer, especially those affecting the CNS, are often not properly reported. Only a few records of tumor statistics satisfy the data requirements of true estimates. Exploring the various hypotheses is laborious and difficult due to lack of standardization of the tumor registries (codification of erroneous classification and differences between the subtype of registered tumor and those confirmed by pathological analysis), regional differences in the health care system, registered tumors without proper histological confirmation, and autopsy rates that prevent a closer picture of reality. With satisfactory regional analyses, statistics could be more realistic.

The notification of cancer cases diagnosed in Brazil is not compulsory, unlike that in developed countries. Statistics obtained from notified cases offer a foundation for health 
Table 1 Number of intracranial neoplasms submitted to surgical resection at Hospital Regional do Oeste (Chapecó, SC, Brazil) between 2013 and 2016, performed by a single surgeon dedicated to neuro-oncology. The data are stratified by patients' age groups

\begin{tabular}{|c|c|c|c|c|c|}
\hline Histology & $\begin{array}{l}0-14 \\
\text { years }\end{array}$ & $\begin{array}{l}15-24 \\
\text { years }\end{array}$ & $\begin{array}{l}25-64 \\
\text { years }\end{array}$ & $\begin{array}{l}>65 \\
\text { years }\end{array}$ & Total \\
\hline Glioma & 6 & 4 & 56 & 12 & 78 \\
\hline Metastasis & - & 1 & 72 & 24 & 97 \\
\hline Lymphoma & - & & 9 & 2 & 11 \\
\hline Meningioma & - & 3 & 44 & 12 & 59 \\
\hline Schwannoma & - & & 18 & 2 & 20 \\
\hline Sellar region & - & 2 & 24 & & 26 \\
\hline Others & 15 & 4 & 27 & 10 & 56 \\
\hline
\end{tabular}

care planning, including decision-making in drug manufacturing and research, funding for health care services, and research of risk factors. Different types of tumors located in the CNS, either primary or metastatic, have specific biological features, treatment, prognosis, and susceptibility to different risk factors. Even benign tumors can lead to death depending on their location, ability to infiltrate local structures, and tendency to become malignant, which hinders a proper classification of CNS tumors and the epidemiological estimates of this pathology. 6,16

In this study, the female gender was more frequent in all histological types analyzed. Although the frequency was only slightly increased, this finding corroborates data obtained in recent studies, which indicate higher prevalence rates of brain tumors among women. ${ }^{17,18}$ This more pronounced increase in the incidence of neuro-oncological involvement in females may suggest the occurrence of risk factors related to sex, with increased use of oral contraceptives, hormone replacement therapy, and infertility treatments emerging as potential explanations. Exposures to electromagnetic fields (such as those from cell phones) and to occupational and chemical hazards have increased considerably over the years and must be evaluated more carefully, regardless of gender as a causal factor.

Aligned with previous studies, ${ }^{19-21}$ we found that the incidence of CNS tumors was the lowest in the youngest age group and increased with age, particularly in the 25-64 years group.

Meningiomas occur mainly in patients between 40-70 years of age and affect women at a rate 2.3 times higher than that in men (12.42 per 100,000 in females and 5.46 per 100,000 in males). ${ }^{22}$ Most meningiomas are considered benign (92.8\%), only $2.2 \%$ are considered atypical, and $5 \%$ are considered malignant. Exposure to ionizing radiation, hormonal factors, genetic polymorphisms, diabetes, smoking, hypertension, epilepsy, and atopy are considered risk factors for these tumors. ${ }^{18}$ In our study, meningiomas were the most common primary brain tumors, followed by highgrade gliomas. These data corroborate those found in recent studies reported by Wöhrer et al, ${ }^{23}$ CBTRUS, $^{22}$ Rockhill et $\mathrm{al}^{24}$ and Barnholtz-Sloan \& Kruchko. ${ }^{25}$
High-grade gliomas were the second most common histological type in our cohort, with glioblastomas emerging as the most frequent gliomas, corroborating findings of other studies. ${ }^{26-31}$ Glioblastomas increase in frequency with age and are rare in children. On histopathology, they have increased cellularity, nuclear atypia, infiltration, necrosis, and vascular proliferation. Its relapsing nature makes this type of tumor difficult to treat, attributing low survival rates (only $2.2 \%$ of the patients survive more than 3 years after diagnosis) and high relapse rates. ${ }^{32}$ Low-grade gliomas corresponded to $26 \%$ of all gliomas. However, when compared with all primary brain tumors, they were only slightly representative in our cohort, comprising only $8 \%$ of the total number of tumors. ${ }^{33}$

Pituitary tumors were particularly frequent in the 25-64 age group in our study. Melmed ${ }^{34}$ and Goel et $\mathrm{al}^{35}$ have observed that these tumors lack gender preference and reach a maximum frequency in the $3^{\text {rd }}$ and $4^{\text {th }}$ decades of life, which is aligned with the results of the present study.

Primary brain tumors did not constitute the majority of the neoplasms analyzed, in detriment of the metastases to the CNS, which corroborates most of the literature on the subject. ${ }^{36-39}$ About $20-25 \%$ of the patients with cancer develop brain metastases, while necropsy-based studies estimate the occurrence of intracranial metastases in up to one third of the patients who die from cancer. ${ }^{40,41}$

The treatment of intracranial tumors includes supportive and definitive therapy. ${ }^{42}$ Supportive treatment ensures symptomatic relief and improvement of neurological function with the administration of agents such as anticonvulsants and corticosteroids, which reduce peritumoral edema, mass effect, and intracranial pressure. These results produce immediate relief of headache and improve neurological manifestations. Definitive treatment, in turn, includes surgery, radiotherapy, and chemotherapy. ${ }^{43}$

Surgical removal is one of the pillars in the treatment of brain metastases, and it remains the best therapeutic option in cases of single brain metastases, especially in public hospitals lacking high technology for proper management of neurosurgical patients. ${ }^{44,45}$ The treatment of brain metastases is individualized and includes, as main options, surgery, corticosteroids, radiotherapy, chemotherapy, and radiosurgery, the latter with an increasingly important role.

Surgery aims at restoring the patients' functional status, improving neurological symptoms and diagnostic confirmation, promoting immediate palliation, and extending the duration of the control of the disease in the CNS, provided that the accessibility and resectability of the tumor are respected. The classic treatment of single brain metastases consists of surgical resection, followed by radiotherapy, providing a median survival of 40 weeks, which is significantly greater than the 15 weeks obtained with radiotherapy as a single treatment. ${ }^{46,47}$ However, compared with radiotherapy alone, there is an increasing preference for radiosurgery on lesions close to eloquent areas. ${ }^{39}$

Considering that the location of the metastases and their relationship with eloquent areas of the brain determine the occurrence of clinical manifestations and therapeutic planning, a proper staging of the primary disease improves the 
24 Profile of Patients with Intracranial Tumors Cunha, Grosbelli

Table 2 Classification (2007 World Health Organization) of intracranial neoplasms submitted to surgical resection at Hospital Regional do Oeste (Chapecó, SC, Brazil) between 2013 and 2016, performed by a single surgeon dedicated to neuro-oncology

\begin{tabular}{|c|c|c|c|c|}
\hline Histology & Males (n) & Females ( $\mathrm{n}$ ) & Total (n) & Total (\%) \\
\hline Glioblastoma & 26 & 18 & 44 & 12.68 \\
\hline Anaplastic astrocytoma & 3 & 2 & 5 & 1.45 \\
\hline Oligodendroglioma & 2 & 5 & 7 & 2.02 \\
\hline Anaplastic oligodendroglioma & 0 & 2 & 2 & 0.58 \\
\hline Ependymoma & 1 & 1 & 2 & 0.58 \\
\hline Ganglioglioma & 0 & 1 & 1 & 0.29 \\
\hline Lymphoma & 6 & 5 & 11 & 3.18 \\
\hline Meningioma & 15 & 44 & 59 & 17 \\
\hline Schwannoma & 10 & 10 & 20 & 6.77 \\
\hline Tumors of the sellar region (pituitary) & 13 & 13 & 26 & 7.49 \\
\hline Craniopharyngioma & 2 & 2 & 4 & 1.16 \\
\hline Neuroblastoma (olfactory, esthesioneuroblastoma) & 3 & 2 & 5 & 1.45 \\
\hline Medulloblastoma & 4 & 2 & 6 & 1.74 \\
\hline Yolk sac tumor & 1 & 0 & 1 & 0.29 \\
\hline Choroid plexus & 1 & 0 & 1 & 0.29 \\
\hline Plasmocytoma & 2 & 0 & 2 & 0.58 \\
\hline Pineocytoma & 2 & 1 & 3 & 0.87 \\
\hline Teratoma (rhabdoid) & 0 & 1 & 1 & 0.29 \\
\hline Dysembryoplastic neuroepithelial tumor & 0 & 2 & 2 & 0.58 \\
\hline Teratoma (mature) & 0 & 1 & 1 & 0.29 \\
\hline \multicolumn{5}{|l|}{ Metastatic } \\
\hline Lung & 31 & 22 & 53 & 15.27 \\
\hline Breast & 0 & 17 & 17 & 4.9 \\
\hline Melanoma & 7 & 5 & 12 & 3.47 \\
\hline Kidney & 1 & 0 & 1 & 0.29 \\
\hline Gastrointestinal & 2 & 7 & 9 & 2.6 \\
\hline Prostate & 2 & 0 & 2 & 0.58 \\
\hline Testicular & 2 & 0 & 2 & 0.58 \\
\hline \multicolumn{5}{|l|}{ Others (unclassified) } \\
\hline Fibrous dysplasia & 4 & 0 & 4 & 1.16 \\
\hline Undifferentiated carcinoma & 3 & 1 & 4 & 1.16 \\
\hline Colloid cyst & 1 & 0 & 1 & 0.29 \\
\hline Hemangioblastoma & 3 & 1 & 4 & 1.16 \\
\hline Dermoid & 1 & 4 & 5 & 1.45 \\
\hline Chordoma & 2 & 0 & 2 & 0.58 \\
\hline Jugulotympanic glomus & 2 & 4 & 6 & 1.74 \\
\hline Low-grade glioma & 11 & 10 & 21 & 6.06 \\
\hline
\end{tabular}

treatment of intracranial metastases. In contrast, in patients with controlled or absent systemic disease, the number, size, and location of the lesions and the patients' clinical conditions determine the best therapy. ${ }^{7,8}$

All types of cancer may metastasize to the CNS, but the rates of occurrence of metastases vary greatly with the tumor's histology. In the present study, lung carcinoma was the most common type of cancer metastasizing to the CNS; this is aligned with findings in the literature, which describe incidence rates ranging from $18-65 \%$, and consider that these metastases occur independently of the control of the primary disease. ${ }^{48-50}$ Breast neoplasms were the second 
most frequent histological type in our study, followed by melanoma, which is also aligned with findings from the literature. ${ }^{38,48-54}$ of note, young and premenopausal patients are more likely to develop brain metastases during the course of breast cancer than elderly and postmenopausal patients; however, the present study found an increased rate of CNS tumors in the more advanced age groups. ${ }^{54-56}$

Despite the small number of cases with melanoma in our series, it is worth mentioning that these tumors are more likely to metastasize to the CNS, ranging from $6-43 \%$ in different clinical series and $12-90 \%$ in autopsy series. ${ }^{57-59}$ There was a predominance of supratentorial metastases (80$85 \%$ of the cases) in the transition between the white and gray matter in the region irrigated by the middle cerebral arteries. $^{39,60}$ Metastases to the cerebellum have a worse prognosis compared with supratentorial metastases due to a higher propensity of these lesions to cause hydrocephalus, hernia, brainstem compression, and death. ${ }^{61}$

Studies involving molecular biology research aim at better understanding the progression of CNS tumors, but studies including regional statistics are also fundamental since they help to identify eventual exposure to carcinogenic factors, launching appropriate public health care policies and treatments, and identifying susceptible population groups.

The neuro-oncology outpatient clinic at the Hospital Regional do Oeste is a referral center for the care of patients with brain tumors in Santa Catarina, Brazil, and the first in the state (to our knowledge, even in the public health system) to count with the combined presence of a neurosurgeon, an oncologist, a radiologist, a pathologist, and a radio-oncologist. This multidisciplinary team providing neuro-oncological care maximizes treatment results, considering that weekly meetings are performed to discuss the cases treated at our outpatient clinic, contributing to the continuous improvement and guaranteeing the excellence of medical services and care provided to the patient.

Limitations of our study include its retrospective design and a potentially biased selection of the patients, whose data were retrieved from a single surgeon's records and may have excluded patients with CNS tumors operated on by other surgeons at the same hospital. The study also did not include patients with CNS tumors seen at the same institution but not undergoing surgery, which may have underestimated patients with certain tumors whose treatment involve medications or radiotherapy alone (such as pituitary tumors and neurinomas). Another limitation of our study was the fact that we only included as epidemiological variables the patients' age and gender, and the tumors' histology and location.

\section{Conclusion}

Questions about the increased incidence of tumors involving the CNS, particularly in elderly patients, have been ongoing for decades and seem to be far from clarified. The lack of reliable records prevents any joint action of health care professionals and government to elucidate possible risk factors and develop concrete public policies to allow for the early diagnosis of neuro-oncological diseases.
Differences in data collection hinder proper estimates of the real incidences when different sources are compared, especially in underdeveloped countries. For now, local statistics may offer the closest estimates from reality to allow the development of public policies in the management of neuro-oncological patients.

\section{Conflicts of Interest}

The authors declare that there are no conflicts of interest.

\section{References}

1 El-Zein R, Minn AY, Wrensch M, Bondy ML. Epidemiology of brain tumors. In: Levin VA, ed. Cancer in the nervous system. 2ed. New York: Oxford University Press; 2002:252-266

2 Samuels MA. Manual of neurology: diagnosis and treatment. 9th ed. LWW: Baltimore; 2007

3 Ministry of Health. National Cancer Institute José Alencar Gomes da Silva. Estimate 2016 - Incidence of cancer in Brazil. Rio de Janeiro: INCA; 2017

4 Cambruzzi E, Zettler CG, Zettler EW, Jotz GP, Grudzinski M, Pedrini J. Immunohistochemical profile of central nervous system metástases. Rev AMRIGS 2009;53(04):382-387

5 Baldi I, Gruber A, Alioum A, et al; Gironde TSNC Registry Group. Descriptive epidemiology of CNS tumors in France: results from the Gironde Registry for the period 2000-2007. Neuro-oncol 2011;13(12):1370-1378

6 Dolecek TA, Propp JM, Stroup NE, Kruchko C. CBTRUS statistical report: primary brain and central nervous system tumors diagnosed in the United States in 2005-2009. Neuro-oncol 2012;14 (Suppl 5):v1-v49

7 Gomes JC, Sá A, Pinto RR, Muñoz V, Coelho C, Monsanto F. Radiosurgical treatment of brain metastases: the relation of histology, brain location and symptoms. Health Tech 2012;7(01):28-32

8 Onishi FJ, Melo JGSP, Melo PMP, Lanzoni OP, Settanni F, Ferraz FAP. Surgical treatment of intracranial metastases. Rev Neurosci 2005; 13(01):11-16

9 Santos AJ, Franco CMR, Borges LRR, Malheiros SMF, Gabbai AA. Brain metastases. Rev Neurosci 2001;9(01):20-26

10 Maldaun MVC. Radiosurgery in the treatment of brain metastases: therapeutic response and complications based on lesion location [thesis]. São Paulo: Faculty of Medicine, Universidade de São Paulo; 2006

11 McDermott MW, Sneed PK. Radiosurgery in metastatic brain cancer. Neurosurgery 2005;57(5, Suppl)S45-S53, S1-S4

12 Louis DN, Ohgaki H, Wiestler OD, et al. The 2007 WHO classification of tumours of the central nervous system. Acta Neuropathol 2007;114(02):97-109

13 Davis DL, Ahlbom A, Hoel D, Percy C, Schwartz J. Is brain cancer mortality increasing in industrial countries? Am J Ind Med 1991; 19(04):421-431

14 Greig NH, Ries LG, Yancik R, Rapoport SI. Increasing annual incidence of primary malignant brain tumors in the elderly. J Natl Cancer Inst 1990;82(20):1621-1624

15 Modan B, Wagener DK, Feldman JJ, Rosenberg HM, Feinleib M. Increased mortality from brain tumors: a combined outcome of diagnostic technology and change of attitude toward the elderly. Am J Epidemiol 1992;135(12):1349-1357

16 Porter KR, McCarthy BJ, Freels S, Kim Y, Davis FG. Prevalence estimates for primary brain tumors in the United States by age, gender, behavior, and histology. Neuro-oncol 2010;12(06): 520-527

17 Kohler BA, Ward E, McCarthy BJ, et al. Annual report to the nation on the status of cancer, 1975-2007, featuring tumors of the brain and other nervous system. J Natl Cancer Inst 2011;103(09):714-736 
18 Claus EB, Bondy ML, Schildkraut JM, Wiemels JL, Wrensch M, Black PM. Epidemiology of intracranial meningioma. Neurosurgery 2005;57(06):1088-1095, discussion 1088-1095

19 McKinley BP, Michalek AM, Fenstermaker RA, Plunkett RJ. The impact of age and sex on the incidence of glial tumors in New York state from 1976 to 1995. J Neurosurg 2000;93(06):932-939

20 Inskip PD, Linet MS, Heineman EF. Etiology of brain tumors in adults. Epidemiol Rev 1995;17(02):382-414

21 Velema JP, Walker AM. The age curve of nervous system tumour incidence in adults: common shape but changing levels by sex, race and geographical location. Int J Epidemiol 1987;16(02):177-183

22 Central Brain Tumor Registry of the United States. CBTRUS statistical report: primary brain and central nervous system tumors diagnosed in the United States in 2004-2008. 2012. Disponível em: http://www.cbtrus.org

23 Wöhrer A, Waldhör T, Heinzl H, et al. The Austrian Brain Tumour Registry: a cooperative way to establish a population-based brain tumour registry. J Neurooncol 2009;95(03):401-411

24 Rockhill J, Mrugala M, Chamberlain MC. Intracranial meningiomas: an overview of diagnosis and treatment. Neurosurg Focus 2007;23(04):E1

25 Barnholtz-Sloan JS, Kruchko C. Meningiomas: causes and risk factors. Neurosurg Focus 2007;23(04):E2

26 Correa C, Soares MS, Cabrera HTN, Figueiredo EG, Teixeira MJ. Gliomas: surgical casuistry in a hospital-quaternary school. Arq Bras Neurocir 2011;30(01):34-37

27 Santos R, Frigeri L, Ordovás C, et al. Epidemiology of tumors of the central nervous system, Our Lady of Pompei Hospital, Neurosurgery Service, about 100 cases studied. Rev Cient AMECS 2001;10 (01):24-32

28 Schwartzbaum JA, Fisher JL, Aldape KD, Wrensch M. Epidemiology and molecular pathology of glioma. Nat Clin Pract Neurol 2006;2(09):494-503, quiz 1, 516

29 Davis FG, Kupelian V, Freels S, McCarthy B, Surawicz T. Prevalence estimates for primary brain tumors in the United States by behavior and major histology groups. Neuro-oncol 2001;3(03):152-158

30 Deorah S, Lynch CF, Sibenaller ZA, Ryken TC. Trends in brain cancer incidence and survival in the United States: Surveillance, Epidemiology, and End Results Program, 1973 to 2001. Neurosurg Focus 2006;20(04):E1

31 Pereira ELR, Rodrigues DB, Viegas MLC, Hermes MN Junior, Burbano RMR. Epidemiology of gliomas in state of Pará - Part I (2000-2006). Arq Bras Neurocir 2012;31(04):200-206

32 Kleihues P, Cavenee WK. Tumors of the central nervous system: pathology and genetics. Lyon: International Agency for Research on Cancer; 1997

33 Ohgaki H, Kleihues P. Epidemiology and etiology of gliomas. Acta Neuropathol 2005;109(01):93-108

34 Melmed S. Update in pituitary disease. J Clin Endocrinol Metab 2008;93(02):331-338

35 Goel A, Nadkarni T, Muzumdar D, Desai K, Phalke U, Sharma P. Giant pituitary tumors: a study based on surgical treatment of 118 cases. Surg Neurol 2004;61(05):436-445, discussion 445-446

36 Sheehan J, Kondziolka D, Flickinger J, Lunsford LD. Radiosurgery for patients with recurrent small cell lung carcinoma metastatic to the brain: outcomes and prognostic factors. J Neurosurg 2005; 102(Suppl):247-254

37 Gavrilovic IT, Posner JB. Brain metastases: epidemiology and pathophysiology. J Neurooncol 2005;75(01):5-14

38 Schuette W. Treatment of brain metastases from lung cancer: chemotherapy. Lung Cancer 2004;45(Suppl 2):S253-S257

39 Maldaun MVC, Pires de Aguiar PH, Zambelli HJL, Sawaya R. Surgical treatment of brain metastases. J Bras Neurosurg 2006; 17(01):14-19
40 Patchell RA. Metastatic brain tumors. In: Brain tumors in adults. Black PM, Wen PY (eds.). WB Saunnders Company; 1995:95-99

41 Thapar K, Laws ER. Tumors of the Central Nervous System. In: Clinical Oncology. Murphy GP, Lawrence W (eds.). American Cancer Society; 1995:424-462

42 Deangelis LM, Loeffler JS, Mamelak AN. Primary brain tumors, Cancer management. A multidisciplinary approach. 8th ed. 2004

43 Correia J, Alexandre JC, Dias C, et al. Glioblastoma Multiforme - A purpose of a clinical case. J Portuguese Soc Int Med 2009;16(01): 27-32

44 Posner JB. Intracranial metastases. In: Neurologic complications of cancer. Posner JB (ed.). FA Davis Company; 1995:77-110

45 Davey P. Brain metastases. Curr Probl Cancer 1999;23(02):59-98

46 Patchell RA, Tibbs PA, Walsh JW, et al. A randomized trial of surgery in the treatment of single metastases to the brain. $\mathrm{N}$ Engl J Med 1990;322(08):494-500

47 Vecht CJ, Haaxma-Reiche H, Noordijk EM, et al. Treatment of single brain metastasis: radiotherapy alone or combined with neurosurgery? Ann Neurol 1993;33(06):583-590

48 Pan HC, Sheehan J, Stroila M, Steiner M, Steiner L. Gamma knife surgery for brain metastases from lung cancer. J Neurosurg 2005; 102(Suppl):128-133

49 Kamada K, Mastuo T, Tani M, et al. Effects of stereotactic radiosurgery on metastatic brain tumors of various histopathologies. Neuropathology 2001;21(04):307-314

50 Bajard A, Westeel V, Dubiez A, et al. Multivariate analysis of factors predictive of brain metastases in localised non-small cell lung carcinoma. Lung Cancer 2004;45(03):317-323

51 Burt M, Wronski M, Arbit E, Galicich JH; Memorial Sloan-Kettering Cancer Center Thoracic Surgical Staff. Resection of brain metastases from non-small-cell lung carcinoma. Results of therapy. J Thorac Cardiovasc Surg 1992;103(03):399-410, discussion 410-411

52 Hernandez L, Zamorano L, Sloan A, et al. Gamma knife radiosurgery for renal cell carcinoma brain metastases. J Neurosurg 2002;97(5, Suppl)489-493

53 Hoshi S, Jokura H, Nakamura H, et al. Gamma-knife radiosurgery for brain metastasis of renal cell carcinoma: results in 42 patients. Int J Urol 2002;9(11):618-625, discussion 626, author reply 627

54 Sheehan JP, Sun MH, Kondziolka D, Flickinger J, Lunsford LD. Radiosurgery in patients with renal cell carcinoma metastasis to the brain: long-term outcomes and prognostic factors influencing survival and local tumor control. J Neurosurg 2003;98(02): 342-349

55 Mystakidou K, Kouloulias V, Tsilika E, et al. Is early recognition of radiologically silent brain metastasis from breast cancer beneficial? A retrospective study of 22 cases. Breast Cancer 2004;11 (03):276-281

56 Slimane K, Andre F, Delaloge S, et al. Risk factors for brain relapse in patients with metastatic breast cancer. Ann Oncol 2004;15(11): 1640-1644

57 Atallah E, Flaherty L. Treatment of metastatic malignant melanoma. Curr Treat Options Oncol 2005;6(03):185-193

58 Daryanani D, Plukker JT, de Jong MA, et al. Increased incidence of brain metastases in cutaneous head and neck melanoma. Melanoma Res 2005;15(02):119-124

59 Sampson JH, Carter JH Jr, Friedman AH, Seigler HF. Demographics, prognosis, and therapy in 702 patients with brain metastases from malignant melanoma. J Neurosurg 1998;88(01):11-20

60 Sawaya R, Ligon BL, Bindal AK, Bindal RK, Hess KR. Surgical treatment of metastatic brain tumors. J Neurooncol 1996;27 (03):269-277

61 Ghods AJ, Munoz L, Byrne R. Surgical treatment of cerebellar metastases. Surg Neurol Int 2011;2:159 